International Journal of Automotive and Mechanical Engineering

ISSN: 2229-8649 (Print); ISSN: 2180-1606 (Online)

Volume 15, Issue 2 pp. 5347-5355 June 2018

(C) Universiti Malaysia Pahang, Malaysia

DOI: https://doi.org/10.15282/ijame.15.2.2018.14.0411

\title{
Effects of Hydraulic Retention Time and Solid Retention Time of POME on COD Removal Efficiency
}

\author{
M. S. Islam* , R. Baini, S. J. Tanjong, M. A. M. Said and E. J. Joy \\ Faculty of Engineering, Mechanical and Manufacturing Department, \\ Universiti Malaysia Sarawak, 94300 Kota Samarahan, Sarawak \\ *Email: mislam@unimas.my \\ Phone: +6082583282; Fax: +6082583410
}

\begin{abstract}
The aim of this paper is to report on the effects of Hydraulic Retention Time (HRT) and Sludge Retention Time (SRT) on the removal of Chemical Oxygen Demand (COD) from palm oil mill effluent (POME). In this study, an upflow anaerobic reactor was used to evaluate the effects of HRT at 6, 8 10, 12 and 15 days. In order to measure the effects of SRT, the 10, 15 and 20 days aged sludge were used. The differences in COD value of POME and effluent at inlet and outlet of the anaerobic reactor were used to measure the effects of HRT and SRT. The experiments were conducted at $35^{\circ} \mathrm{C}$ for a length of 60 days, and input-output data of COD were used to achieve the research objectives. The estimated results show that the COD removal was optimum at 12 days of HRT and the estimated COD removal performance was at 40.4 percent. It was also found that COD removal was optimum at 20 days of SRT and the estimated COD removal performance was at 34.1 percent. The study concluded that anaerobic reactor is an effective method to remove COD from POME. This study recommends future researches which aim to increase COD removal to level that is economically and environmentally sustainable.
\end{abstract}

Keywords: Hydraulic retention time; solid retention time; COD removal; palm oil mill effluent; anaerobic reactor.

\section{INTRODUCTION}

Malaysia is the largest palm oil producer in the world, which accounts for 17.73 million tonnes of palm oil and 2.13 tonnes of palm kernel oil a year [1-3]. During palm oil production, a huge amount of wastes is produced including POME. Basically, POME is a by-product of palm oil mills. POME is identified as hazardous effluent due its toxic properties. POME has acidic properties $(\mathrm{pH} \leq 4)$ with high level of biological oxygen demand (BOD), chemical oxygen demand (COD), emission of greenhouse gas (GHG) including methane and carbon dioxide make this effluent unfit for the environment. Despite its hazardous characteristics, POME is also a potential source of soil, water and air pollution which if not treated well, can reduce health quality of people and contributes to reduce economic growth [3-5]. The outputs of palm oil mill process and POME generation are shown in Figure 1. 


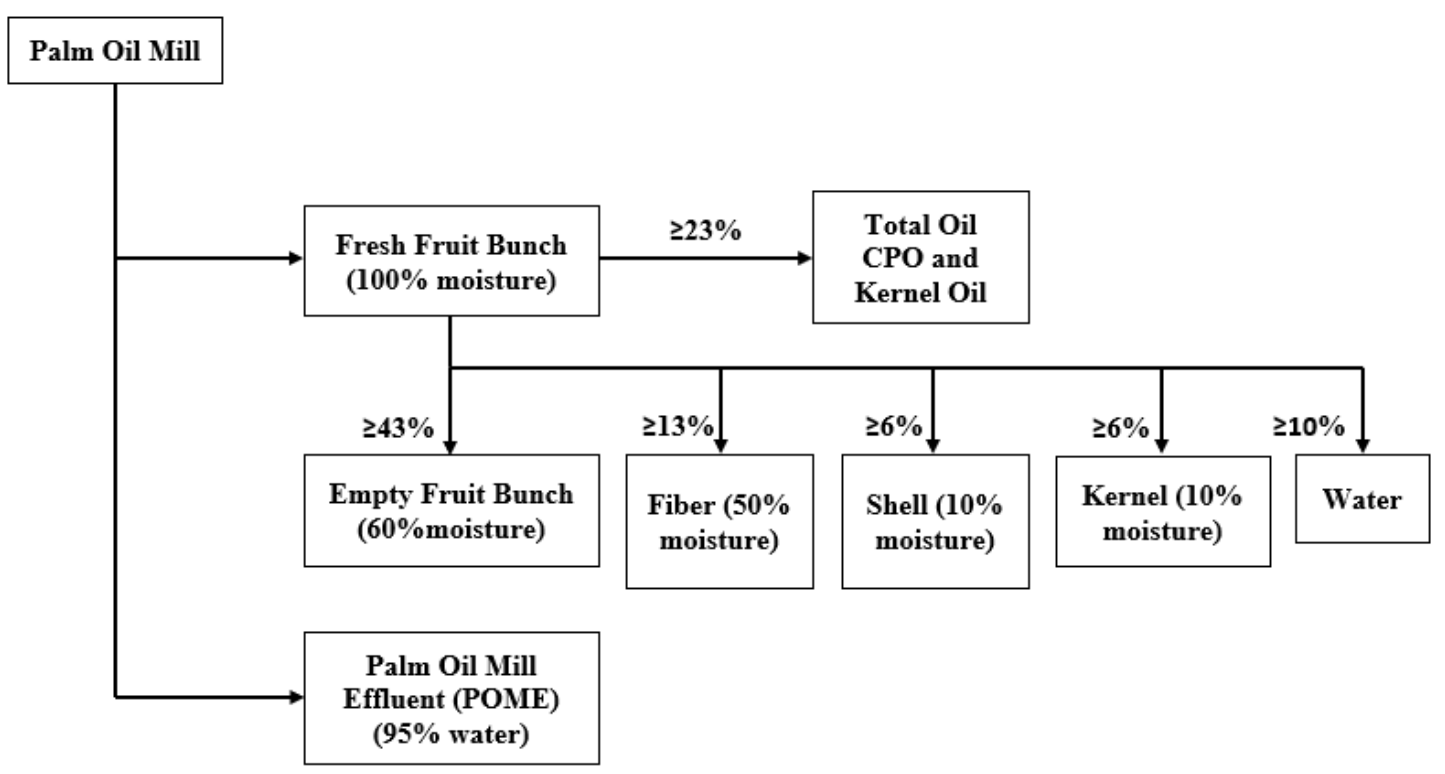

Figure 1. POME generation process [2].

POME is produced during crude palm oil (CPO) production from Fresh Fruit Bunch (FFB) and is a mixture of water, microparticles of biomass of FFB and some polluted organic substances. It has been reported that POME generation rate is about $1.5 \mathrm{~m}^{3} / \mathrm{tCPO}$ [2]. Some basic and important parameters relating to pollution are listed in Table 1.

Table 1. Characteristics of POME.

\begin{tabular}{lccc}
\hline Parameter & $\begin{array}{c}\text { Wong et al. 2009 } \\
{[6]}\end{array}$ & $\begin{array}{c}\text { Muhammad et al. } \\
2015[7]\end{array}$ & $\begin{array}{c}\text { Bello et al. 2013 } \\
{[8]}\end{array}$ \\
\hline $\mathrm{pH}$ & $4.15-4.45$ & $3.5-4.5$ & $3.4-5.2$ \\
$\mathrm{BOD}_{3}(\mathrm{mg} / \mathrm{L})$ & $21,500-22,500$ & $16,500-22,500$ & $10,250-43,750$ \\
$\mathrm{COD}(\mathrm{mg} / \mathrm{L})$ & $45,500-65,000$ & $50,000-110,000$ & $15,000-100,000$ \\
Total solid $(\mathrm{mg} / \mathrm{L})$ & $33,790-37,230$ & $25,000-36,000$ & $11,500-79,000$ \\
Total volatile solid & $27,300-30,150$ & $21,000-33,000$ & $20,000-40,000$ \\
$(\mathrm{mg} / \mathrm{L})$ & & & \\
\hline Note: Biological Oxygen Demand $(B O D)$ &
\end{tabular}

The data listed in Table 1 indicates that POME needs to consume more than $20,000 \mathrm{mg}$ oxygen to decompose the biomass that is available in a litre of effluent $[3,4]$. $\mathrm{Wu}$ et al. stated that this amount is significantly higher as compared to other effluents [5]. The listed data also suggest that POME requires about $100 \mathrm{~g} / \mathrm{L}$ of oxygen to decompose its COD [5]. When fresh POME discharges into water bodies it tends to consume required oxygen from the water bodies in order to decompose its biomass and organic materials. It was reported that this phenomenon causes oxygen shortage in the water bodies $[9,10]$ which consequently affects the ecological system with intensified biodiversity loss $[2,10]$.

The current POME treatment technology typically consists of biological aerobic digestion. Biologically treated effluent is disposed to land application system for providing essential nutrients to plants. It has been reported that approximately 95 
percent of POME treatment have been performing by using the Waste Stabilization Ponds (WSP) method. A major percentage of POME has been discharging into water bodies [9]. It was also reported that WSP is often poorly managed and is not effective in achieving required effluent quality. Furthermore, the HRT of this method is about 100 days, which require a large amount of land area. Figure 2 describes the outcome of a conventional POME treatment method $[2,9]$.

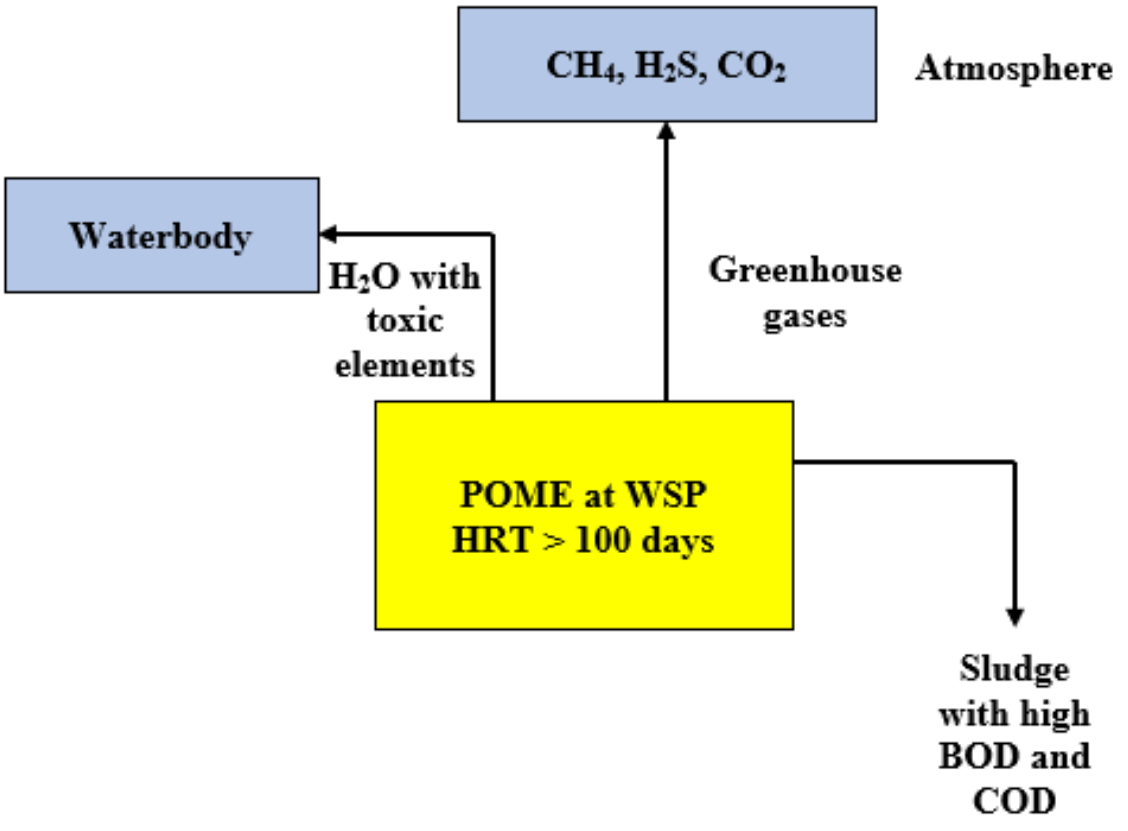

Figure 2. Conventional POME treatment.

Figure 2 demonstrates that WSP is a source of biogas ( $\mathrm{CH} 4$ and $\mathrm{CO} 2)$ production, which emits to the atmosphere as greenhouse gas (GHG). A small part of hydrogen sulphate $\left(\mathrm{H}_{2} \mathrm{~S}\right)$ is also produced which emits through the WSP treatment process. These GHGs are responsible for air pollution and global warming [2]. On the other hand, treatment performance of WSP is significantly poor in terms of COD and BOD removal $[2,9,10]$. With this research background, the study on COD reduction using anaerobic reactor is designed. This study was formulated to address some of the drawbacks of conventional waste stabilisation pond method. In this study, the optimum reduction of COD from POME without the emission of GHG is evaluated.

\section{PROBLEM STATEMENT AND OBJECTIVES}

Many new methods and technologies have been developed to solve problems related to POME treatment. However, it has been stated that palm oil mills are struggling to produce quality effluent as per the specification set up by the Department of Environment (DOE) [11]. The established fact is that the conventional ponding system and open digesting tanks were not environmentally friendly due to the requirements of huge surface areas and poor performance of reducing COD and BOD [10,11]. Although advanced technologies have been implemented to solve this problem, still a part of the problem exists as the required HRT for treating POME is about 20 days. This information indicates that a research gap exists in this domain. Thus, this research is 
designed to optimize HRT for COD reduction from POME. Indeed, this research attempt to address the question of 'how to optimize COD removal from POME?'.

To address the research question, the broad objective of this study was to optimize COD reduction from POME to a sustainable level. Hence, to achieve this broad objective the following sub-objectives were outlined:

a) To determine the optimum HRT on COD removal.

b) To determine the optimum of SRT on COD removal.

\section{METHODOLOGY}

The main components of the research methodology are as follows: experimental setup, sample collection and experimental procedure, POME samples testing, data collection and model estimate. The following subsections discuss each component in more detail.

\section{Experimental setup}

The experiment was designed to achieve the research goals and accordingly, equipment was organized. The layout of equipment installation is shown in Figure 3. The major equipment and machinery of this experiment are feed tank, feed pumps, anaerobic reactor, flow switch (FS) and effluent collection tank. The capacity of the plant is 500 litres per hour of POME. The detail of the experimental setup is illustrated in Figure 3.

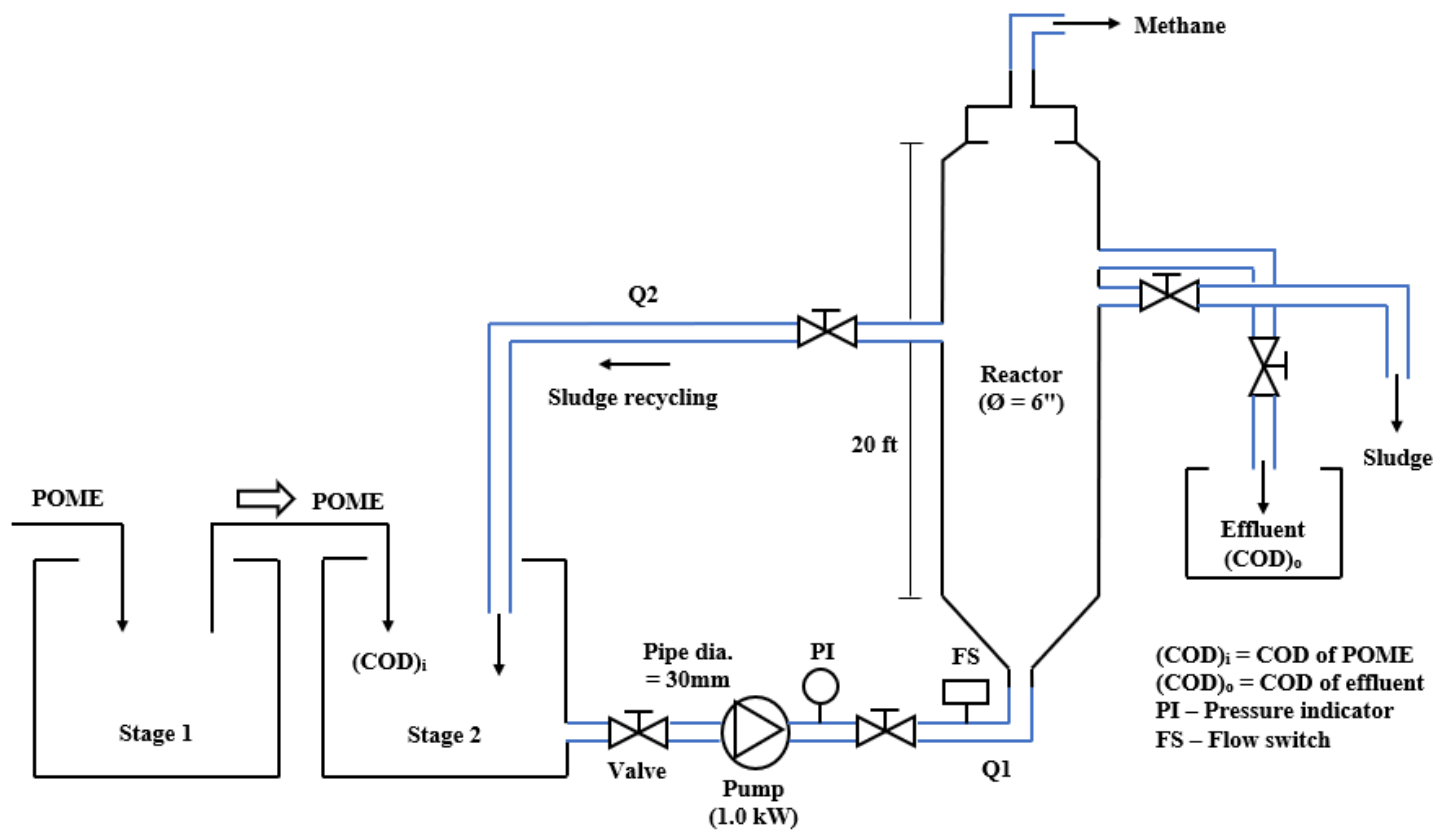

Figure 3. Experimental setup at Operations Research Lab, Faculty of Engineering, UNIMAS.

\section{Sample Collection and Experimental Procedure}

Fresh POME was collected from Bau Palm Oil Mill (BAPOM), located nearby Kuching of Sarawak. A number of 25-litre high-density polyethylene (HDPE) containers were 
used to transport the POME from BAPOM to the operations research laboratory at Universiti Malaysia Sarawak.

Two tanks were used for initial processing of POME and formation took place in these tanks. The feed rate of POME to the anaerobic reactor was 500 litre per hour which was controlled by FS. The upflow velocity of POME was 1.0 meter/minutes. The $\mathrm{pH}$ and temperature of POME were 7.0 and $35^{\circ} \mathrm{C}$, respectively. The $\mathrm{C} / \mathrm{N}$ ratio of feed was 15. The HRT of POME was 6, 8, 10, 12, and 15 days. The age of the sludge was 10,15 , and 20 days. The organic loading rate was $2.5 \mathrm{~kg} / \mathrm{m} 3$ of POME $[12,13]$. The sludge was recycled into the feed tank to increase the contact time in order to speed up the decomposition speed $[12,14]$. The effluent and sludge were collected through a pipe as shown in Figure 3.

\section{Data Collection}

In every set of experiment with respect to HRT and SR, the $\mathrm{COD}_{\mathrm{i}}$ of POME at inlet, and $\mathrm{COD}_{\mathrm{o}}$ of effluent at outlet were recorded. Every hour, effluent sample was collected for COD test and the total samples were 8 per day. In 60 days of experiment, total 480 samples were collected. SPSS software was used to improve the data quality and to perform data normalization. Only normal distributed data were used to carry out the model estimate.

\section{Mathematical Model}

The HRT, SRT, temperature, $\mathrm{pH}$, flow rate and OLR are the controlling factors of decomposing COD. The parameters HRT and SRT can be expressed as in the following Eq. (1) and (2) respectively.

HRT $(\mathrm{t})=$ Volume of aeration tank $\left(\mathrm{m}^{3}\right) /$ Influent flow rate $\left(\mathrm{m}^{3} / \mathrm{hr}\right)=\mathrm{V} / \mathrm{Q}$

$\mathrm{SRT}=$ Sludge mass in the digester/Sludge discharge rate $=\mathrm{X}_{\mathrm{i}} \mathrm{V} / \mathrm{QX} \mathrm{X}_{\mathrm{x}}$

where $X_{i}$ is the mixed liquid suspended solids (MLSS), $V$ is the reactor volume, $Q$ is the excess biosolids removal rate, and $X_{x}$ the MLSS in the excess biosolids flow.

\section{COD Reduction Performance Estimate Model}

The difference of COD in POME and COD in effluent is a measure of anaerobic reactor performance in COD reduction. The COD reduction performance can be measured by Eq. (3) and (4).

$\Delta \mathrm{COD}=\mathrm{COD}_{\mathrm{i}}-\mathrm{COD}_{\mathrm{o}}$

and COD reduction in percent:

$\Delta \mathrm{COD} \%=\left[\left(\mathrm{COD}_{\mathrm{i}}-\mathrm{COD}_{\mathrm{o}}\right) / \mathrm{COD}_{\mathrm{i}}\right] \times 100 \%$

where $\mathrm{COD}_{\mathrm{i}}$ is $\mathrm{COD}$ in POME and $\mathrm{COD}_{\mathrm{o}}$ is $\mathrm{COD}$ in effluent. 
In this study, the independent variables are HRT and SRT. The dependent variables is COD reduction. The parameters of HRT were $6,8,10,12$, and 15 days; and the parameters of SRT were 10, 15, and 20 days [13,14].

\section{MODEL ESTIMATE AND RESULTS}

\section{Effects of HRT on COD removal}

The results on the average COD of POME and effluent is shown in Table 2. To evaluate the performance of the anaerobic reactor in terms of COD reduction, these data were estimated using Eq. (3) and (4).

Table 2. Effect of HRT on COD Removal

\begin{tabular}{l|ccccc}
\hline HRT (days) & 6 & 8 & 10 & 12 & 15 \\
\hline COD of Influent (mg/L) & 51,000 & 51,000 & 51,000 & 51,000 & 51,000 \\
Average COD of Effluent* (mg/L) & 38,400 & 37,760 & 35,200 & 30,400 & 32,000 \\
Average COD removal rate (\%) & 24.7 & 26.0 & 30.1 & 40.4 & 37.3 \\
\hline *at pH 4.5, SRT 20 days, Upflow velocity & 1.0 meter/minutes, OLR $2.5 \mathrm{~kg} / \mathrm{m3}$ pome, C/N ratio 15[14]
\end{tabular}

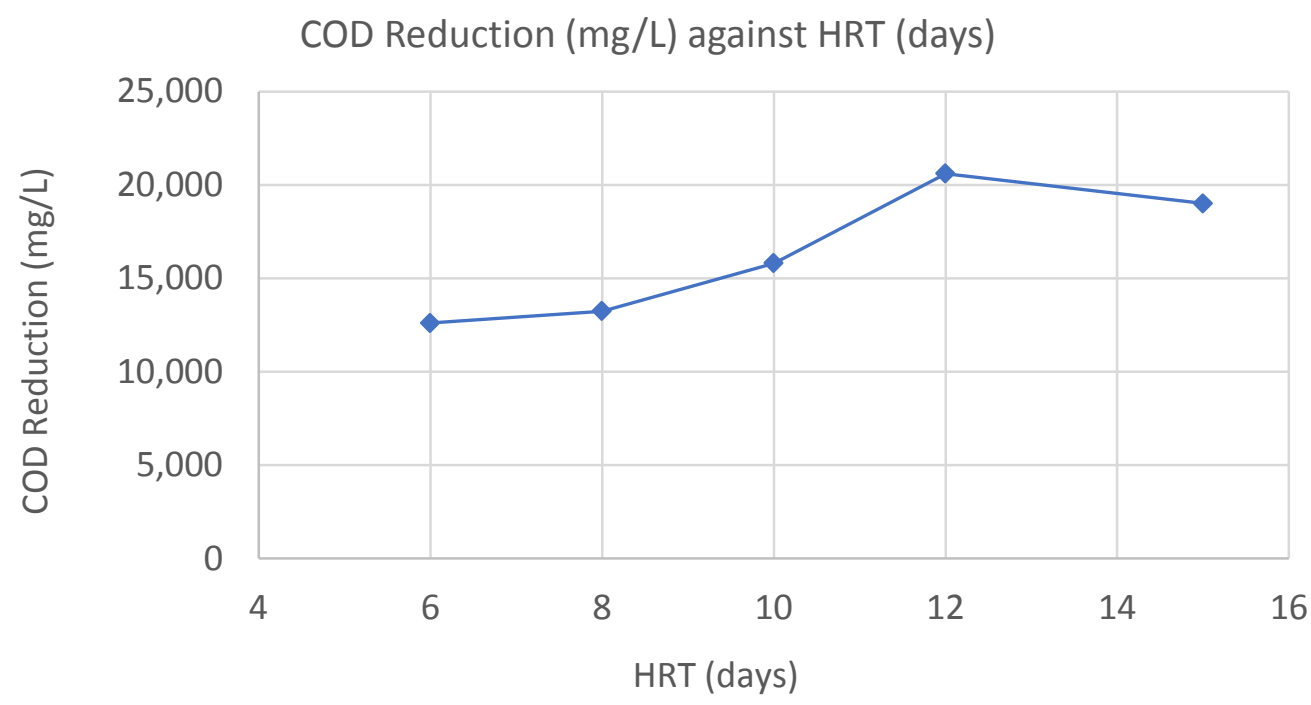

Figure 4. COD reduction (mg/L) with respect to HRT (days).

As demonstrated in Figure 4, the COD reduction increased from 6 HRT to 12 HRT and the reduction range was from 24.7 percent to 40.4 percent. However, the COD reduction at 15 HRT was 37.3 percent, which is a lower reduction value compared to the reduction taking place at 12 HRT. Based on this condition, it can be stated that the maximum COD reduction occurred at $12 \mathrm{HRT}$. It indicates that at the given operating conditions of anaerobic reactor, COD reduction is positively associated with HRT although after $12 \mathrm{HRT}$, COD reduction performance tends to reduce. 


\section{Effects of SRT on COD removal}

The results on the average COD of POME and effluent is shown in Table 3. To evaluate the performance of the anaerobic reactor in terms of COD reduction, these data were estimated using Equations (3) and (4).

Table 3. Effect of SRT on COD removal.

\begin{tabular}{lccc}
\hline SRT (days) & 10 & 15 & 20 \\
\hline COD of Influent (mg/L) & 51,000 & 51,000 & 51,000 \\
COD of Effluent* (mg/L) & 41,200 & 38,340 & 33,620 \\
COD removal rate (\%) & 19.2 & 24.8 & 34.1 \\
* at $p$ H.5, HRT 10 days, Up flow velocity 1.0 meter/minutes, ORL 2.5kg/m3 pome, C/N ratio 15[14]
\end{tabular}

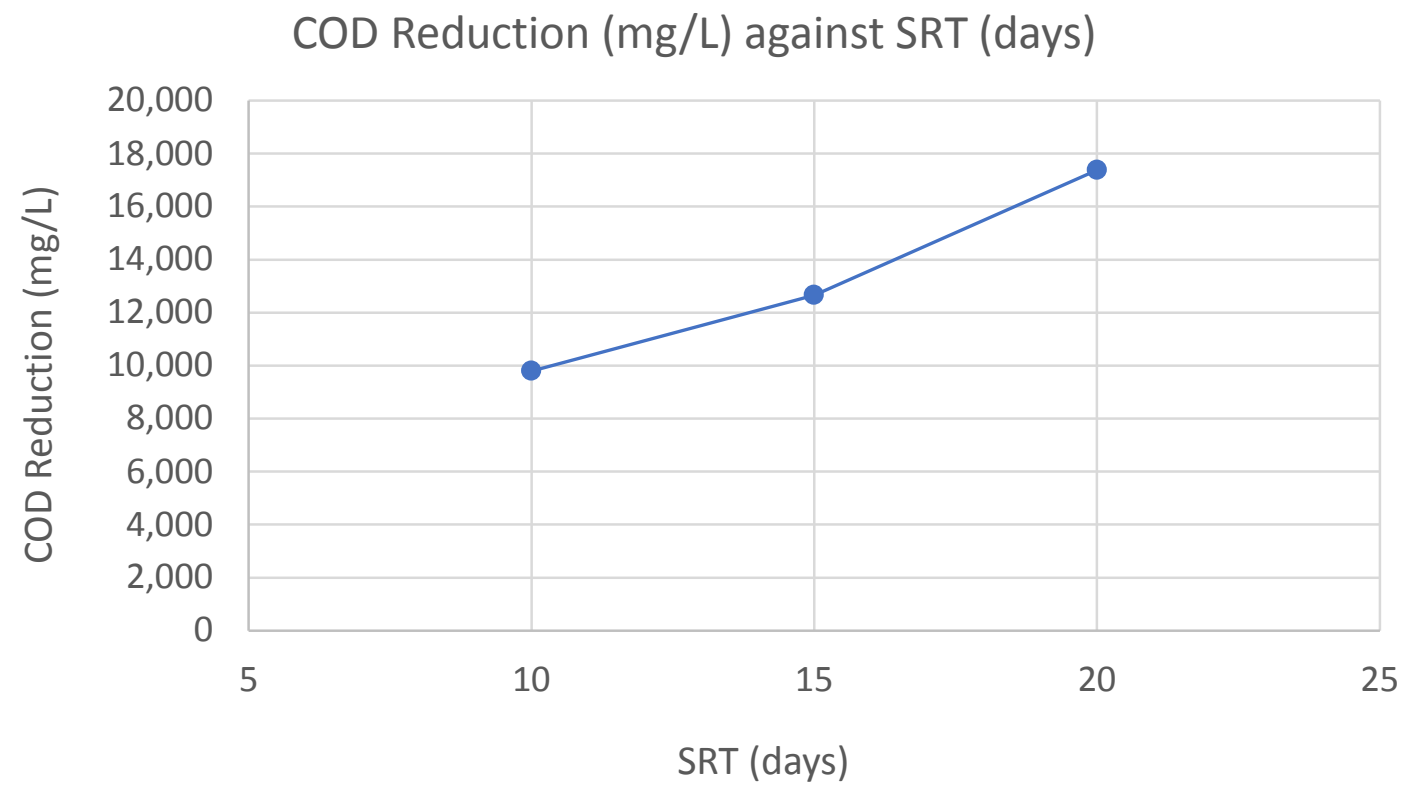

Figure 5. COD reduction $(\mathrm{mg} / \mathrm{L})$ with respect to SRT (days)

Figure 5 shows that the COD reduction increases with SRT ranging from 10, 15 and 20 SRT and the percent reduction was from 19.2 percent to 34.1 percent. Based on this condition, it can be started that the maximum COD reduction occurred at 20 SRT. It indicates that at the given operating conditions of anaerobic reactor, COD reduction is positively associated with SRT.

\section{RESULTS AND DISCUSSION}

The current research aimed to reduce COD from POME with the aid of anaerobic reactor in order to replace WSP. It was found that optimum HRT was 12 days, which contributed to the reduction of COD by 40.4 percent and COD reduction was from $51,000 \mathrm{mg} / \mathrm{L}$ to $30,400 \mathrm{mg} / \mathrm{L}$. Thus, the findings based on the first objective demonstrated that HRT has a positive effect on COD reduction in the anaerobic condition. 
The result shows that COD removal of POME was 34.1 percent at 20 days of SRT and COD reduction was from $51,000 \mathrm{mg} / \mathrm{L}$ to $33,620 \mathrm{mg} / \mathrm{L}$. Thus, the findings on second objective demonstrated that SRT has a positive effect on COD reduction in the anaerobic condition.

The COD reduction 40.4 percent at $12 \mathrm{HRT}$ and 34.1 percent at $20 \mathrm{SRT}$ is significantly poor compare to findings of other researches. For example, Wong et al. (2013) found COD reduction 87.08 percent at $12 \mathrm{HRT}$, while he used anaerobic reactor for POME treatment [15]. Similar research findings had reported by Faisal et al (2016) [13]. Indeed, in both cases, COD reduction had appeared poor which may be due to the experiment being conducted at lower $\mathrm{pH}$ and $\mathrm{C} / \mathrm{N}$ ratio [16]. However, both HRT and SRT contribute to the reduction of COD from POME. In this aspect, the answer of the research question is that HRT and SRT are able to reduce COD from POME as both are positively associated with COD reduction.

\section{CONCLUSION}

Most palm oil mills in Malaysia are still using the conventional ponding system to treat POME. Thus, the research on COD removal from POME with the aid of anaerobic bioreactor was conducted to add new knowledge to the current technology of POME treatment. The first objective of this research was to determine the optimum HRT on COD removal. It was found that the optimum HRT was at 12 days giving the COD removal rate and concentration of $40.4 \%$ and $30,400 \mathrm{mg} / \mathrm{L}$ respectively. The second objective of this research was to determine the optimum SRT on COD removal. The study resulted in the finding that the optimum SRT on COD removal of POME was at 20 days. The COD of effluent was $33,620 \mathrm{mg} / \mathrm{L}$ giving a removal rate of $34.1 \%$. For future studies, researches on anaerobic treatment of POME which addresses the effects of $\mathrm{pH}$ on COD removal rate is recommended. Other factors such OLR, upflow velocity, temperature and carbon to nitrogen ratio, with the objective of improving the COD removal efficiency shall also be considered. Consideration of these other factors can contribute to better outcomes to the output parameters, such as lower biochemical oxygen demand and greater yield of methane gas. Anaerobic bioreactor is proven to be a successful technique and it has been used by many researchers to treat different types of wastewater. Anaerobic treatment of POME is beneficial to palm oil mills because it brings positive contributions to the environment, industry, society and economy.

\section{ACKNOWLEDGEMENT}

The authors express their sincere appreciation to the Bau Palm Oil Mill (BAPOM) management staff for supporting this research. Authors also express their gratitude for the supports received from Faculty of Engineering, Universiti Malaysia Sarawak in completing this work. This work was supported by State Ministry of Agriculture, Sarawak, the grant no GL/F02/ORSSG/2016.

\section{REFERENCES}

[1] MPOC. Malaysia Palm Oil Corporation - Oil Palm Plantation. 2017. Retrieved from: http://www.mpoc.org.my/The_Oil_Palm_Tree.aspx.; July 2017 
[2] Islam MS, Lamoh MM, Advanced Eco-farming Technology to Achieve Sustainable Agriculture Growth in Sarawak. Sarawak: UNIMAS Publisher, 2017.

[3] Wakker E. Greasy palms. The social and ecological impacts of large-scale oil palm plantation development in Southeast Asia, F.o.t. Earth; Friends of the Earth: London; 2005

[4] Ahmad A, Ismail S, Bhatia S. Water recycling from palm oil mill effluent (POME) using membrane technology. Desalination, 2003; 157(1): 87-95.

[5] Wu TY, Mohammad AW, Jahim JM, and Anuar N, Pollution control technologies for the treatment of palm oil mill effluent (POME) through end-ofpipe processes. Journal of Environmental Management, 2010; 91(7): 1467-1490.

[6] Wong YS, Kadir MOAB, and Teng TT. Biological kinetics evaluation of anaerobic stabilization pond treatment of palm oil mill effluent. Bioresource Technology, 2009; 100(21): 4969-4975.

[7] Muhammad S, Abdul WM, Mohd Tusirin MN, Siti RSA, and Hassimi AH. Investigation of Three Pre-treatment Methods Prior to Nanofiltration Membrane for Palm Oil Mill Effluent Treatment. Sains Malaysiana, 2015; 44(3): 421-427.

[8] Bello MM, Nourouzi MM, Abdullah LC, Choong TSY, Koay YS, and Keshani $\mathrm{S}$. POME is treated for removal of color from biologically treated POME in fixed bed column: Applying wavelet neural network (WNN). Journal of Hazardous Materials, 2013; 262: 106-113.

[9] Ng WJ, Goh ACC, and Tay JH. Palm oil mill effluent treatment (POME) - an assessment of coagulants used to aid liquid-solid separation. Biol. Wastes, 1978; 21: 237-248.

[10] Sheil D, Casson A, Meijaard E, van Noordwjik M, Gaskell J, SunderlandGroves J, Wertz K, and Kanninen M. The impacts and opportunities of oil palm in Southeast Asia: What do we know and what do we need to know?, Bogor, Indonesia: Center for International Forestry Research (CIFOR); 2009

[11] Madaki YH, and Lau S. Palm oil mill effluent (POME) from Malaysia palm oil mills: waste or resource. International Journal of Science, Environment and Technology, 2013; 2(6): 1138 - 1155

[12] Kardos L, Juhász A, Palkó GY, Oláh J, Barkács J, and Záray GY. Comparing of mesophilic and thermophilic anaerobic fermented sewage sludge based on chemical and biochemical tests. Applied Ecology and Environmental Research, 2011; 9(3): 293-302.

[13] Faisal M, Machdar I, Gani A, and Daimon H. The combination of air flotation and a membrane bioreactor for the treatment of palm oil mill effluent. International Journal of Technology, 2016: 7(5).

[14] Lenntech Water treatment solutions. 2010. Retrieved from: http://www.lenntech.com/wwtp/srt.htm; 2017

[15] Wong YS, Teng TT, Ong SA, Norhashimah M, Rafatullah M, and Lee HC. Anaerobic acidogenesis biodegradation of palm oil mill effluent using suspended closed anaerobic bioreactor (SCABR) at mesophilic temperature. Procedia Environmental Sciences, 2013; 18: 433-441.

[16] Mahmoud N, Zeeman G, Gijzen H, and Lettinga G. Anaerobic stabilisation and conversion of biopolymers in primary sludge - effect of temperature and sludge retention time. Water Research, 2004; 38(4): 983-991. 